\title{
The Relationship of Academic Achievement with Graduation of Nurse Preference Competency Test at STIKes Panrita Husada Bulukumba
}

\author{
Safruddin 1 , Muriyati ${ }^{*}$, Jasrullah ${ }^{3}$ \\ Departemen Community and Family Nursing , Stikes Panrita Husada Bulukumba, Indonesia ${ }^{1}$ \\ Departemen Surgical Medical Nursing, Stikes Panrita Husada Bulukumba ,Indonesia ${ }^{2}$ \\ S1 Nursing Study Program, Stikes Panrita Husada Bulukumba, Indonesia ${ }^{3}$
}

Corresponding Autor : muriyati.stikes@gmail.com*

\begin{abstract}
National competency test is one of the effective ways to improve the educational process and management of achieving competency relevance in accordance with the competency standards required by the community. Data obtained at the Panrita Husada College of Health Sciences Bulukumba Nurse Profession in taking the 2014 Competency Test average GPA of 3.94 with a competency test reaching $62.9 \%$, then in 2015 an average GPA of 3.73 with a competency test graduation $48.6 \%$ and in 2016 with an average GPA of 3.75 passing the competency test is decreasing at $35.7 \%$. And it can be concluded that from year to year the passing of competency tests has decreased. The purpose of this study was to determine the relationship between academic achievement and the graduation of the Nursing Professional Competency test for Stikes Panrita Husada Bulukumba. This study uses a cross-sectional design. The sample of this study was 155 respondents with a population of 155 professional students of Stikes Panrita Husada Bulukumba. The analysis used was univariate and bivariate analysis using statistical tests of alternative unpaired T-test Mann Whitney with a significance level $(\alpha=0.05)$. The results showed that based on the results of statistical analysis using the Mann Whitney test, the value of $\mathrm{p}=0.001<\alpha=0.05$ based on the final results can be concluded that there is a relationship between academic achievement with the passing of the Competency Test for Nurses Stikes Panrita Husada Bulukumba. The conclusion in this study is the academic achievement of competent Ners Stikes Panrita Husada Bulukumba students has a higher number than those who are not competent. More competency tests passed and those that did not. There is a difference in the proportion between academic achievement who passed the Ners Stikes Panrita Husada Bulukumba professional competency test.
\end{abstract}

Keywords: Competency Test, Learning Process, Academic Achievement

\section{INTRODUCTION}

Health workers are one of the most important factors in supporting the function of the health service system. It requires competent and dedicated health workers in good numbers and distribution to be able to carry out their roles and functions optimally. Improving the quality of education for health workers is one of the strategic steps to have relevant competencies to run the health service system. One effort to encourage the acceleration of improvement and equitable quality of education for health workers is to improve the quality control of education graduates. National competency test is an 
effective way to improve the educational process and management of achieving competency relevance following the competency standards required by the community (Ristek Dikti, 2016).

Competency test is a process of measuring the knowledge, skills and behavior of students in tertiary institutions holding a tertiary education in health midwives. National competency test is held by universities in collaboration with professional organizations. The organizing is carried out by the organizing committee determined by the decision of the Minister of Research, Technology and Higher Education. This test is intended to achieve work competency standards. Besides, the national competency test can be used as part of education quality assurance (2016 Dikti Research and Technology). Based on Law Number 12 of 2012 Article 44 the authority to grant competency certificates has been explained, but the certification process mechanism has not yet been explained. For this reason, the government is obliged to provide competency test system standards that apply nationally to ensure the quality of the implementation of competency tests. More technically, Law Number 36 of 2014 concerning health personnel and Law Number 38 of 2014 concerning nursing have been issued, more explicitly mandating a national competency test. Following article 21 paragraph (7) of Law Number 36 of 2014, the procedures for conducting competency tests are governed by Ministerial regulations, in this case the Ministry of Research, Technology and Higher Education (Ristek Dikti 2016).

In Indonesia 385 there are undergraduate education institutions (nurses) and 478 nursing D3, there are 48 institutions conducting nurses education so far, while 220 other institutions are following. On one hand there is an extraordinary disparity in ability between educational providers in producing graduates. On the other hand must protect the public from the actions of nurses who have been declared graduated and have diplomas that are not yet competent. Competency test results in Indonesia graduation rate of $50 \%$ (Kariasa, 2014). Achievement is always associated with the implementation of an activity or activities. Academic achievement is inseparable from learning activities, learning activities are processes, while academic achievement is the output of the learning process. According to Poerwodarminto (1995) in Puspitasari W, 2011. achievement is the result that has been achieved, carried out or done by someone, while learning achievement is the achievement achieved, a student in a certain period. 


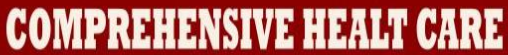

According to Ola, Es, 2015 achievements are concrete skills or results that can be achieved at certain times or periods. Effective learning can help students to improve their abilities following the instructional goals to be achieved. To improve good learning achievement, internal and external conditions need to be considered. The Wicaksono A study, 2014. said thirty-one doctors of the 2005 batch (the first batch) participated in this study, with a record of 11 doctors graduating in November 2010.5 doctors in January 2011 and 15 doctors in June 2011. There was a decrease in the mean Index Cumulative Achievement and Average of Indonesian Doctors Competency Test from each period. There is a significant and quite strong relationship between the Cumulative Achievement Index and the value of the Indonesian Doctors Competency Test so in conclusion, there is a significant relationship between the Cumulative Achievement Index and the value of the Indonesian Doctors Competency Test.

Data obtained at the Panrita Husada College of Health Sciences Bulukumba Nurse Profession in participating in Competency Test in 2014 an average GPA of 3.94 with a competency test reaching $62.9 \%$, then in 2015 an average GPA of 3.73 with a graduation test competence of $48.6 \%$ and in 2016 with an average GPA of 3.75 passing the competency test is decreasing at $35.7 \%$. And it can be concluded that from year to year the passing of competency tests has decreased. The impact of not passing the competency test can not yet get STR (registration certificate) to be able to work must have STR and pass the competency test. So that researchers are interested in examining "The Relationship of Academic Achievement to the passing of the Competency Test for Nurses Stikes Panrita Husada Bulukumba.

\section{MATERIAL AND METHODS}

In this type, the independent and dependent variables are assessed at one time, so there is no follow up. Of course, not all research subjects must be observed on the same day or at the same time, but both the independent and dependent variables are assessed only once. With this study the prevalence or effect of a phenomenon (dependent variable) will be associated with the cause (dependent variable) (Nursalam, 2016).In this study, researchers will observe the GPA and the results of competency tests at one time unit. The population in this study were all Nursing Profession students who had taken competency tests, namely 155 Nurse Stikes Professors Panrita Husada Bulukumba students. 
The sample is part of the number of characteristics possessed by the population (Sugiyono, 2012). The sampling technique is a sampling technique. To determine the sample used in the study, various sampling techniques are used (Sugiyono 2012). As for the sampling technique in this research, namely the Total Sampling technique which is a method of selecting samples which is done by taking all the population that is used as a respondent. (Sugiono, 2012).

The research instrument is a tool used by researchers to observe, measure or assess a phenomenon. Data obtained from a measurement are then analyzed and made as evidence (evidence) from a study. So the instrument or measuring instrument is an important part in a study (Dharma, 2013). The instrument of this study was to determine academic achievement in the form of observation and to determine the passing of competency tests using the Stikes Panrita Husada Bulukumba ners profession observation sheet. Bivariate analysis is performed to determine the relationship between independent variables and dependent variables. The statistical test used is the alternative unpaired $\mathrm{T}$ test mann withney test This test aims to see whether or not there are differences in the average GPA on alumni who pass the competency test by not passing the competency test expected with a significance level of 0.05 . If P-Value $<0.05$ means there is a significant relationship (Ho is rejected) while P-Value $>0.05$ has no meaningful relationship (Ho is accepted).

\section{RESULTS}

Table 1. Characteristics Of Respondents By Gender And Year Of Competency Test

\begin{tabular}{lcc}
\hline Characteristics & (n) & Percentage (\%) \\
\hline Gender & & \\
Male & 38 & 24,5 \\
Female & 117 & 75,5 \\
Year Of Competency Test & & \\
Year 2014 & 62 & 40,0 \\
Year 2015 & 37 & 23,87 \\
Year 2016 & 56 & 36,12 \\
\hline Amount & 155 & 100 \\
\hline
\end{tabular}

Based on table 1 above shows that the number of male respondents was 38 people (24.5\%), and the number of female respondents was 117 people (75.5\%), then those who took the competency test in 2014 were 62 people, in 2015 as many as 37 people, and in 2016 as many as 36 people. 
Table 2. Distribution of Academic Achievement of Nursing Profession STIKes Panrita Husada Bulukumba

\begin{tabular}{lcc}
\hline \multicolumn{1}{c}{ Academic achievement } & (n) & Percentage (\%) \\
\hline Praise & 45 & 29,0 \\
Very satisfy & 88 & 56,8 \\
Satisfying & 20 & 12,9 \\
Less satisfactory & 2 & 1,3 \\
\hline Amount & $\mathbf{1 5 5}$ & $\mathbf{1 0 0 , 0}$ \\
\hline
\end{tabular}

Based on table 2 above shows that Academic Achievement with honors GPA as many as $45(29.0 \%)$, GPA predicate is very satisfying as many as 88 (56.8\%), the predicate GPA is satisfying as many as $20(12.9 \%)$ and less satisfactory predicate as many as 2 (1.3\%).

Table 3 Distribution of Nurse Profession Frequency Based on passing Competency Test

\begin{tabular}{lcc}
\hline \multicolumn{1}{c}{ Competence test } & (n) & Percentage (\%) \\
\hline Competence & 79 & 51.0 \\
Not Competence & 76 & 49.0 \\
\hline Amount & 155 & 100,0 \\
\hline
\end{tabular}

Based on table 3 above, it shows that the competency test has $79(0.79 \%)$ competent criteria and $76(0.76 \%)$ incompetents.

Table 4. Analysis of the relationship between academic achievement and passing the professional competency test

\begin{tabular}{|c|c|c|c|c|c|c|c|}
\hline \multicolumn{8}{|c|}{ Graduation Competency Test } \\
\hline \multirow[t]{2}{*}{ Academic achievement } & \multicolumn{2}{|c|}{ Competence } & \multicolumn{2}{|c|}{ Not Competence } & \multicolumn{2}{|c|}{ Amoun } & p Value \\
\hline & $\mathrm{n}$ & $\%$ & $\mathrm{n}$ & $\%$ & $\mathrm{~N}$ & $\%$ & \\
\hline Praise & 43 & 95,60 & 2 & 4,40 & 45 & 100,0 & \\
\hline Very satisfy & 33 & 37,50 & 55 & 62,50 & 88 & 100,0 & $<0,001$ \\
\hline Satisfying & 3 & 15,00 & 17 & 85,00 & 20 & 100.0 & \\
\hline Less satisfactory & 0 & 0,000 & 2 & 100,00 & 2 & 100,0 & \\
\hline Amount & 79 & 51,00 & 76 & 49,00 & 155 & 100,0 & \\
\hline
\end{tabular}

Based on table 4 above shows that academic achievement with predicate GPA of competent praise as many as 43 people (95.60\%), incompetent as many as 2 people (4.40\%), academic achievement with predicate GPA is very satisfying who are competent as many as 33 people (37.50\%), 55 people (62.50\%), inadequate academic achievement with satisfactory GPA as many as 3 people (15.00\%), 17 people $(85.00 \%)$ inept, academic achievement with the predicate of unsatisfactory GPA of 2 people (100.00\%). Based on the results of statistical analysis using the Mann Whitney test, the value of $p=0.001<\alpha=0.05$ based on the final results can be concluded that there is a 
relationship between academic achievement and graduation of the professional competency test of Panikita Husada Bulukumba STIKes.

\section{DISCUSSION}

Based on research conducted at the STIKes Panrita Husada Bulukumba campus in Academic Achievement with a GPA of 45 (29.0\%), a very satisfying GPA of 88 (56.8\%), a GPA of $20(12.9 \%)$ ) and unsatisfactory predicate of 2 (1.3\%). This is in line with the Poerwodarminto theory that Achievement is always associated with the implementation of an activity or activities. Academic achievement is inseparable from learning activities, learning activities are processes, while academic achievement is the output of the learning process. Furthermore Puspitasari explained that achievement is the result that has been achieved, done or done by someone, while learning achievement is the achievement achieved, a student in a certain period of time.

This is also explained in the Notoatmodjo theory that achievement is an impetus that is present in every human being to achieve the results of their activities or work results optimally. Instinctively everyone has the need to do or do his activities better than before, and if possible to be better than others. The results of this study are in line with the results of previous studies Alvin Abdillah, 2016 states that good academic achievement in the final phase of learning will more easily understand the concepts or theories that have been obtained and will also be easier to remember so that their intellectual abilities increase accompanied by increased technical abilities therefore the student will easily work on the exam questions so that the results obtained will also be satisfying.

As for the researchers' assumption, that high academic achievement can improve the results of competency exam graduation because the higher the level of one's intelligence, the ability to master and digest student-lessons learned in class is also easier. That way, the level of student pride when facing a competency exam is not too heavy due to the strong understanding and ability of students to analyze exam questions. In addition, students will find it easier and confident to do the exam questions in accordance with the specified time duration and get the results as expected. Based on research conducted at the Stikes Panrita Husada Bulukumba campus on passing the competency test, the competency test obtained had 79 (51.0\%) competent criteria and 76 (49.0\%) incompetents. 


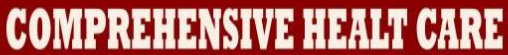

The results of this research are in line with the 2016 Higher Education Research and Technology theory, Competency test is a process of measuring the knowledge, skills and behavior of students in tertiary institutions conducting higher education of health midwives. Competence can be defined as a basic characteristic of individuals who have a causal relationship or cause and effect with criteria that are used as a reference, effective or superior appearance at work in certain situations. This is also in line with the theory of Kepmendiknas 045/2002 competency is a set of smart, responsible actions owned by a person as a condition to be considered capable by the community in carrying out tasks in certain job midwives. The "Four Pillars" (the Four Pillars of UNESCO) that underlie Minister of Education Decree No. 232 / U / 200 is someone who is competent must be able to meet the basic requirements of the ability to develop personality.

As for the researchers' assumptions, passing a competency test can improve competence in the quality of education of health workers and improve quality control of education graduates so they can work professionally in health care facilities, at this stage it can provide opportunities to work in hospitals. Based on the results of statistical analysis using the Mann Whitneydi test, the value of $p=0.001<\alpha=0.05$ based on the final results can be concluded that there is a relationship between academic achievement and passing the competency test of Nurses Stikes Panrita Husada Bulukumba. The results of the study are consistent with Arif Wicaksono's 2014 research, with the title of the researcher being the relationship between the cumulative achievement index and the competency test scores of Indonesian doctors on doctors graduating from Tanjungpura University. This research method is a cross sectional analytic study. The population in this study were all Indonesian doctors at 31 graduates from Tanjungpura University. Univariate analysis research design using Spearman correlation. Thirty-one doctors from 2005 (first batch) participated in this study, with a record of 11 doctors graduating in November 2010, 5 doctors in January 2011 and 15 doctors in June 2011. There was a decrease in the average GPA and UKDI average from each period there is a significant and quite strong relationship between the CPI and the UKDI score.

Likewise, the research conducted by Alvin Abdillah, 2016 with the research title Analysis of Factors Affecting the Graduation of Indonesian Nurses Competency Test, one of which was examined is the relationship between the Cumulative Achievement Index 


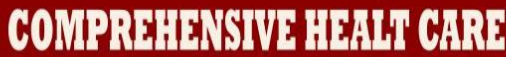

to UKNI graduation. This shows that there is a relationship between the Cumulative Achievement Index with UKNI Graduation .

\section{CONCLUSIONS}

There is a relationship between academic achievement who passed the Ners Stikes professional test Panrita Husada Bulukumba . In order that the results of this study can provide information for Nurse Professionals so that they often attend lectures given by lecturers, in order to know the factors that can cause the competency graduates not to graduate.

\section{REFERENCES}

Abdilla, A. (2016). Analis Faktor - Faktor Yang Mempengaruhi Kelulusan Uji Kompetensi Ners Indonesia. JPA jurnal Penelitian Administrasi Publik.

Buku Panduan Penyusunan SKRIPSI Program Studi S1 Keperawatan STIKES Panrita Husada Bulukumba 2016/2017

Efendi. (2012). Pendidkan dalam Keperawatan . Jakarta: Salemba Medika.

http://kelembagaan.ristekdikti.go.id/wp-content/uploads/2016/08/LAMPIRANPERMEN-NOMOR-12-TAHUN-2016-TENTANG-UII-KOMPETENSINAKES-SALINAN.pdf diakses pada tanggal 3 Pebruari 2017.

http://www.kopertis12.or.id/wpcontent/uploads/2014/06/permen tahun 2014 nomor049.pdf diakses pada tanggal 6 pebruari 2017.

http://gajiroum.kemkes.go.id/gajiroum/data/UU NO 36 2014.pdf

di akses pada tanggal 6 pebruari 2017.

Hidayat, A. A. (2014). Metode Penelitian Keperawatan dan Teknik Analisa data. Jakarta Selatan: Salemba Medika.

Kariasa, Cert 2014. Blue Print Ujian Nasional Perawat, di Kutif dalam Power Poin. KNEPK, (2012). Etika Penelitian

Kristini, R. E. (2010). Hubungan Antara Motivasi Belajar dengan Prestasi Akademik pada Mahasiswa Prodi Keperawatan S1 Program A. Angkatan 2 Stikes RS. Babtis Kediri. Jurnal Stikes Rs. Babtis . 


\section{COMPRAHENSWEHABH CARE}

Kusuma, D. (2013). Metodologi Penelitian Keperawatan. Jakatra Timur: CV Trans Info Media Katalog Dalam.

M, T. (2016). Belajar dan Pembelajaran. Yogyakarta: Ar-Ruzz Media.

Muhibbin, S. (2011). Psikologi Belajar. Jakarta: Rajawali Pers.

Mulyani, D. (2013). Hubungan Kesiapan Belajar Siswa dengan Prestasi Belajar . Konselor Jurnal Ilmiah Konseling .

Notoatmodjo, S. (2014). Ilmu Prilaku Kesehatan . Jakarta: Renika Cipta.

Nursalam. (2016). Metode Penelitian Keperawatan . Jakarta: Salemba Medika.

Ola, S. E. (2015). Hubungan Minat dan Motivasi dengan Prestasi Belajar Mahasiswa Akbid Bira yudhistira Tangerang . Jurnal IImu Kebidanan Indonesia .

Pambudi, P. S. (2012). Hubungan Konsep Diri dengan Prestasi Akademik pada Mahasiswa Keperawatan . Jurnal Nursing Studies .

Sugiyono. (2012). Metodolgi Penelitian Kuantitatif, Kualitatif, dan $R$ dan D. Bandung: Alfabeta CV.

Wicaksono, A. (2014). Hubungan Antara Indeks Prestasi Kumulatif dan Nilai Uji Kompetensi Dokter indonesia pada Dokter lulusan Universitas Tanjung Pura. Jurnal Visi Ilmu Pendidikan .

Widya, P. (2012). Hubungan Antara Manejemen Waktu dan Dukungan Sosial dengan Prestasi Akademik Mahasiswa yang Bekerja. Universitas Ahmad Dahlan . 